\title{
Contextual Teaching and Learning as a Medium to Improve National Character Values in Science
}

\author{
Hendra \\ Chemical Education Department \\ Faculty of Teaching and Education Training \\ Universitas Lambung Mangkurat \\ Banjarmasin, Indonesia \\ hendra.a1c310019@yahoo.co.id
}

\author{
Muhammad Kusasi \\ Chemical Education Department \\ Faculty of Teaching and Education Training \\ Universitas Lambung Mangkurat \\ Banjarmasin, Indonesia \\ Muhammadkusasi64@gmail.com
}

\begin{abstract}
Implantation of national character values in the process of teaching and learning is a important. Implantation the value of characters in the learning process is expected to improve the student's personality to be even better person. The problem is now how to apply the value of the national character in learning especially science teaching and learning. The solution for this problem is to use the Contextual Teaching and Learning (CTL) approach. It is because the CTL component can facilitate the appearance of the national character value.
\end{abstract}

Key Words: National Character Values, Contextual Teaching and Learning (CTL), Science Lesson

\section{INTRODUCTION}

Character education becomes the main issue of education in the 21 st century. In addition to being part of the process of moral formation of the nation, character education is expected to be the main foundation in the success of Indonesia Gold 2045. Indonesia needs human resources in sufficient quantity and quality as the main support in development. To meet the human resources, education is important. Life progress of a nation is determined by education. Well-organized education can create intelligent human resources, scientific, noble character/air character, critical-creative, knowledgeable and independent [1].

The national education serves to develop the ability and shape the character and civilization of the nation's dignity in the context of the intellectual life of the nation. Establishing and developing are important characters in the course of education. The young generation of Indonesia based on the above national educational goals is expected not only to have knowledge and skills alone, also must have good character and nationalism [2]. Character education is an effort to educate children to make decisions wisely and practice it in our daily lives so that they can make a positive contribution to the environment [3].

Today the picture of easy-generation behavior has begun to degenerate. Any time we can see from news reported by newspapers and electronic media that showed a lot of commendable behavior of the younger generation in this country. Character, ethics, and morals begin to be ignored. The irony is that this has permeated the life of the learner. Like students who show less respect for adults, cheating cases that have become a habit, bullying a group of people (gang) to exclude a person who has a physical or mental weakness, as well as the use of illegal drugs consumed by students. Young people seem to increasingly damage themselves and others, and are increasingly unconcerned to contribute to the welfare of their fellow human beings. In these circumstances they reflect society's sick that need moral and spiritual renewal [4].

The cultivation of character values both at school and in the home environment is seen to be lacking. This can be greatly felt in education. The case of cheating (cheating) in the form of acts of cheating, modeled after the work of a friend as well as textbook as if it were an everyday occurrence. Even in the implementation of the final examination of schools such as the National Final Examination in an area allegedly there are teachers provides the key answers to students.

To prevent more severe moral crisis, these efforts have been initiated through the nation of character education curriculum embodied in 2013. In this curriculum 2013, students are not only equipped with knowledge alone but includes several other important aspects such as skills and behavior. In the implementation of curriculum of 2013 in the school, cultivation of character values given is integrated in the learning process on the subjects. What is meant by the planting of character values are integrated in the learning process is the introduction of values, the facility gained awareness of the importance of value - value, and internalization values into the behavior of students daily through a learning process either takes place within and outside the classroom [4]. For example, in science subjects, science learning objectives can be selected in accordance with a bloom taxonomy, which covers the realm of knowledge, attitudes, and skills.

Science subjects have been given at the level of secondary education as an integral part of the subjects of physics, chemistry and biology. In a junior level, IPA (Natural Science) is implemented by involving all aspects of student learning outcomes whether cognitive, psychomotor and affective. Science learning is also required to be made for 
students to actively learn by doing investigations and skills to carry out various related to skills of learning. Additionally, Science learning also emphasizes the value formation student's character to inculcate a positive attitude of learning such as self-confidence, tiliti, honest, disciplined, willing to work together, tolerance and etc. However, the problem is teachers sometimes only deliver material that focusing on cognitive without any implications for the lives of the students in the community in other words without involving psychomotor and affective. It is the task of the teachers teaching science to be able to instill character values in science learning to the students. This is rarely or never done by the teachers, so teachers are highly required to be creative and look at the needs of students for the future.

Difficulties experienced by teachers in growing the value of the character (affective) learning can be reduced with contextual teaching and learning approach. This approach not only to grow the value of the character but also can facilitate the increasing student achievement of learning outcomes of cognitive and psychomotor.

Based on the explanation above, the authors were interested in writing this paper to present the idea "Contextual Teaching and Learning for Medium to Grow Character Values Nationality in Junior Science Lesson". The purpose of this paper was to understand about the theoretical studies and conceptual learning of the contextual teaching and learning (CTL) against the value of character nationality in science lesson of junior high school [5].

\section{METHOD}

The research uses the document and literature to explain the national character values through Contextual Teaching and Learning (CT). Literarture review uses the book, and journal.

\section{RESULT AND DISCUSSION}

\section{A. Character education is worth the nationality}

a) Value

Value is the price in terms of interpretation, quality levels. Based on this understanding, it can be summed up that value is as something useful, valuable, quality, and can be utilized by others [6]. Values refer to something abstract, not a concrete object that can be seen directly. Thus, to detect a value must be through interpretation against another reality in the form of action, behavior, mindset and attitude of a person or group of people. The value is enabled to direct, control, and defines a person's behavior, because the value is the standard of behavior.

\section{B. Character}

The word comes from the Greek characters to mark which means marking and focusing on how to apply the value of goodness in form of action [7]. Director General of Islamic Education, Ministry of Religious Affairs of Republic Indonesia suggested that the character is defined as personal characteristics which are inherent and can be identified on the behavior of individuals who are unique [8]. Based on the above opinion, the authors can conclude that the character is a state of the soul possessed by the man himself which then becomes the basis for distinguishing each individual. Character is unique, meaning that the character of each individual is different from other individuals. Character makes a person has a characteristic in doing an action or behavior that is done in daily life.

Character is the typical values, good character, morals or personality formed from the result of internalization of various policies that are believed and used as a way of thinking, thinking, behaving, saying and behaving in everyday life. A character person means a person who has personality, behavior, character, character, or character. With significance as it means the character is identical with the personality or character.

\section{National Character Values}

In the National Policy of Nation Character Development, it is mentioned that the character of the nation is a characteristic quality of collective nationalism-whether reflected in the awareness, understanding, taste, intention and behavior of the nation and state as the result of thought, if the heart, sense and intention, and sports a person or a group of people. The character of the Indonesian nation will determine the collective behavior of the Indonesian nation typical wellreflected in the awareness, understanding, taste, intention, and behavior of nation and state of Indonesia based on Pancasila values, norms 1945, diversity under the principle of unity in diversity, and commitment against the Homeland Government of the Republic of Indonesia [9].

Furthermore, it is mentioned that for the progress of the Republic of Indonesia, we need to be strong, competitive, noble, moral, tolerant, cooperative, patriotic, dynamic, cultured, and science-oriented characters based on Pancasila and inspired by faith and piety to God Almighty. Character based on the philosophy of Pancasila means that every aspect of character must be imbued in the five precepts of Pancasila as a whole and comprehensively include: 1) a nation of God Almighty, 2) a nation that upholds a just and civilized humanity, 3) a nation that puts the unity and unity of the nation , 4) a democratic nation and uphold the law and human rights, and 5) the nation that puts fairness and prosperity of the Republic of Indonesia's instructions of goverment [9].

The education in Indonesia has 18 values of characters that need to be implanted to students who come from Religion, Pancasila, Culture, and National Education Goals [10]. Eighteenth values are: 1) religious, 2) honest, 3) tolerance, 4) discipline, 5) hard work, 6) creative-critical, 7) independently, 8) democratic, 9) curiosity, 10) spirit nationality, 11) love of the homeland, 12) appreciates the achievements / others, 13) friends / communicative, 14) love peace, 15) likes to read, 16) concerned about the environment, 17) of social care, 18) responsibility. Although it has been formulated there are 18 values forming the character of the nation, every educational unit can determine the priority of its development. Selection of these values is based on the 
interests and conditions of each educational unit. This is done through context analysis, so that in its implementation, it is possible that there are different types of character values developed.

\section{Contextual Teaching and Learning (CTL)}

Contextual Teaching and Learning (CTL) is a learning approach that emphasizes the relation between context and meaning. This learning guides students to combine academic subjects with the context of their own circumstances and give meaning to it. CTL is also an educational process that aims to help students see the significance of academic material by linking with the academic subjects in the context of a student's daily life, with personal contexts, environmental, social and cultural [11]. CTL is a learning approach that helps teachers connect the content of subject matter to real-life situations and to motivate students to make connections between knowledge and application into the family environment, the community environment and the work environment [12].

CTL is an approach that connects teaching and learning to students with diverse life contexts and prepares students for a more complex learning environment for their future careers.

\section{E. Components of Contextual Teaching and Learning (CTL)}

The CTL approach has several distinctive components that distinguish it from other approaches CTL components are used in the following lessons [11].

1. Making meaningful connection, students establish link between the learning contexts with real-life context.

2. Doing significant work (do important work), students do work that has a purpose and useful.

3. Self-regulated learning (learning to manage themselves) students can set himself as a person who is active learning

4. Collaborating (cooperation) students can work together.

5. Critical and creative thinking (thinking critically and creatively) students can use a higher level of thinking critically and creatively; can analyze, synthesize, solve problems, make decisions, and use evidence and logic.

6. Nuturing the individual (nurture people), nurture private student: know, pay attention, giving high hopes, motivate and reinforce students.

7. Reaching high standard (achieving high standards) identify clear objectives and motivate students to reach it.

8. Using authentic assessment (held authentic assessment).

The CTL component are concept linkages (relating), the concept of practice directly (experiencing), the concept of application (applying), the concept of cooperation, the concept of self-regulation (self-regulating) and the concept of authentic assessment [13].

\section{F. Contextual Teaching and Learning (CTL) and the national character in junior high school science teaching}

Based on a CTL component can be given of the embodiment of national character values as follows:

1. Constructivism is building understanding itself of new experiences based on prior knowledge and learning which should be packed into a process of "constructing", not receiving knowledge. The application of constructivism learning theory in learning can develop various characters, including critical and logical thinking, self-reliance, love science, curiosity, respect for others, responsible, and confident.

2. Inquiry (find) is the process of moving from observation into understanding, and students learn to use critical thinking skills. Learning that applies the principles of inquiry can develop a variety of characters, including critical thinking, logical, creative, and innovative, curiosity, respect for others' opinions, courteous, honest, and responsible.

3. Questioning is the teachers 'activities to stimulate, guide, assess students' thinking skills. Learning that uses questions to guide students to achieve learning goals can develop various characters, including critical and logical thinking, curiosity, respect for others' opinions, courteousness, and self-confidence.

4. Learning community is a group of people who are bound in learning activities, with the concept that learning together is better than studying alone. In this activity students can exchange experiences or exchanging ideas. The application of the principles of the learning community in the learning process can develop a variety of characters, among others, cooperation, respect for the opinions of others, courteous, democratic, obedient to social, and responsibility.

5. Modeling is the process of the appearance of an example so that other people think, work, and learn. Students will perform activities that are modeled by the teacher through the model. Modeling in learning, among others, can cultivate curiosity, respect for others, and self-confidence.

6. Authentic assessment (assessment of the actual) is an activity measure students' knowledge and skills. Authentic assessment is assessing the product (performance), then chores students relevantly and contextually. The real assessment will foster the value of honesty, independence, confidence, sense of responsibility.

7. Reflection is a way of thinking about what they have learned, write them down, and keep a journal, artwork, discussion groups. Reflections in learning, among others, can foster the ability to think logically and critically, knowing the advantages and disadvantages of yourself, and appreciate the opinions of others.

\section{CONCLUSION}

Contextual Teaching and Learning (CTL) approach is the models to apply the character value in . It is because the CTL component can facilitate the appearance of the national character value. 


\section{REFERENCES}

[1] I.G.A. Rusmiati, I W. Santyasa and W.S. Warpala, "Pengembangan Modul Ipa dengan Pendekatan Kontekstual untuk kelas V SD Negeri 2 Semarapura Tengah", e-Journal Program Pascasarjana Universitas Pendidikan Ganesha Program Studi Teknologi Pembelajaran Volume 3, 2013

[2] Depdiknas, Law no. 20 of 2003, National Education System, Chapter II Article 13, 2003

[3] D. Kesuma, Character Education, Bandung: PT Remaja Rosda karya, 2011

[4] T. Lickona, Thomas, Educating for Character, Translation Lita S. Character Education. Bandung: Nusa Media, 2013

[5] A. Sahlan, and A.T. Prastyo, Design Based Learning Character Education. Yogyakarta: Ar-Ruz Media, 2012

[6] H.B. Nimpuno, Indonesian Dictionary, New Edition. West Jakarta: Pandom Media Nusantara, 2014

[7] F. Pupuh, Character Education Development, Bandung: PT. Refika Aditama, 2013
[8] Mulyasa, Management of Character Education, Jakarta: Earth Literacy, 2011

[9] N.S. Darmawan, On the National Character Education Implementai Students In College, Papers for the Development of Education Character 1 Students Environmental Kopertis PTS in Region VIII, posted, Udayana University, Denpasar, 2014

[10] Kemendiknas, Character Education Implementation Guide, Jakarta: Research and Development Center of Curriculum and Book Center Jakarta, 2011

[11] E.B. Jhonson, Contextual Teaching and Learning Make Learning Activities clicking engrossing and meaningful teaching, Bandung: Kaifa Learning, 2010

[12] R.G. Bens, and P.M. Ericson, Contextual Teaching and Learning: Preparing student for the Eonomy, The Highlight Zone: Work No. 5 Washington DC Office of Vational Adult Education, 2001

[13] K. Komalasari, Contextual Learning Concepts and Applications, Bandung: PT RefikaAditama, 2011. 